\title{
2015 a Talajok Nemzetközi Éve
}

A 2015-ös évet az ENSZ 68. Közgyülése a Talajok Nemzetközi Évének nyilvánította, december 5-ét pedig a Talaj Világnapjának. „A Talajok Nemzetközi Éve 2015" rendezvénysorozat elsődleges célja az volt, hogy minden ember számára tudatosítsa a talaj alapvető szerepét az élelmiszertermelésben, az élelmiszerbiztonságban, a fenntartható fejlődésben, az éghajlatváltozás hatásainak enyhítésében, a természeti értékek és az élhető környezet fenntartásában, vagyis az emberi élet minőségének alakulásában.

Az emberi életminőség nélkülözhetetlen eleme a megfelelő mennyiségü és minőségủ élelmiszer, a tiszta víz, valamint a kellemes környezet. A három környezeti elem szorosan összefügg a talajok minőségi és mennyiségi jellemzőivel. A talajtannal foglalkozó kutatók és oktatók számára a talajok jelentősége egyértelmü, ugyanakkor a felnövő generáció tagjainak meg kell tanítani, hogy a talaj mennyire sokszínü és milyen sokféle funkciójú. A hazai talajtant művelő tudósoknak válaszokat kell adnia a mezőgazdasági szakemberek és döntéshozók kérdéseire. Feladatuk a még megválaszolatlan kérdésekre a válaszok kidolgozása. A talajhasználók köre igen tág és sokrétü. A talajvédelem ezért össztársadalmi feladat. A védelem érdekében össztársadalmi együtt gondolkodás szükséges. A talajok ésszerủ használata és védelme ugyanis a fenntartható társadalmi fejlődés záloga. Ezért tartották a talajokkal foglalkozók kivételesen nagyjelentőségünek a Talajok Nemzetközi Évét 2015-ben.

Az ENSZ Élelmezésügyi és Mezőgazdasági Szervezete (FAO), valamint a Nemzetközi Talajtani Unió (IUSS) számos eseményt szervezett 2015-ben. A talaj évének nyitó eseményét az ENSZ székházában - a Talaj Világnapján - rendezték New York-ban 2014. december 5-én, a FAO székházban pedig Rómában és Bangkokban. A római $\mathrm{FAO}$ központban $\boldsymbol{A}$ termötalaj a családi gazdálkodás alapja címmel tartották az ünnepi megemlékezését. A nyitórendezvényen Magyarország egy alföldi csernozjom talajmonolitot adományozott a FAO-nak. Az ünnepélyesen átadott talajszelvény „kézzel fogható bizonyitéka a FAO-val való kiváló együttmüködésünk elismerésének és közös munkánk iránti elkötelezettségünknek" mondta Bartha Péter, a Földművelésügyi Minisztérium föosztályvezetője.

A hazai talajtani szakma mühelyei tudományos és ismeretterjesztő rendezvényekkel járultak hozzá a talajok jelentőségének minél szélesebb körủ megismertetéséhez. Jelen összefoglalás a Talajok Nemzetközi Évéhez kapcsolt - kutatáson, oktatáson, illetve szakmapolitikai rendezvényeken kívüli - rendezvényeket és eseményeket tekinti át.

A Magyar Talajtani Társaság (MTT) 2014. december 17-én a Szent István Egyetemen rendhagyó ünnepi közgyuulést tartott, ahol Michéli Erika elnök asszony a 2015-ös évet a Talajok Nemzetközi Éveként jelentette be és köszöntötte. 
Az elnök asszony beszámolt a 2015. évben tervezett eseményekröl, melyek szervezése elkezdődött és kérte, hogy minél több és széles körben meghirdetett esemény legyen a talajok ünneplése érdekében.

A Földművelésügyi Minisztérium Darányi Ignác termében nyitórendezvényként az Egészséges talajok az egészséges életért címmel 2015. március 9-én rendeztek Talajvédelmi konferenciát a Talajok Nemzetközi Éve alkalmából tudós és oktatói szakemberek, valamint szakmapolitikusok részvételével. Szalkai Gábor főosztályvezető-helyettes köszöntötte a megjelenteket, majd Fazekas Sándor földművelésügyi miniszter köszöntője után beszédet mondott Vladimir Rakhmanin, a FAO európai és közép-ázsiai regionális képviselője. Győrffy Balázs a Nemzeti Agrárgazdasági Kamara elnöke, Márai Géza, az Ökológiai Egyesület elnöke, illetve Michéli Erika, a Magyar Talajtani Társaság elnöke köszöntéseit követően Simon Attila István, az FM közigazgatási államtitkára, Dobi Bálint, az FM Környezetmegőrzési Főosztály vezetője és Szalkai Gábor, az FM Élelmiszerlánc-felügyeleti Főosztály vezető helyettese tartott előadást a talajvédelem fontosságáról, a talajok élelmiszerláncban betöltött szerepéről. Michéli Erika, Németh Tamás, Birkás Márta, Várallyay György, Pálmai Ottó, Maucha Gergely, Mindszenty Andrea és Farkas László előadásaikban érzékeltették a talajok multi-funkcionalitását és az emberi életminőség alakulásában betöltött szerepét. Zárszóként Németh Tamás, az MTA rendes tagja a talajvédelem fontosságát emelte ki és üdvözölte a Talajok Nemzetközi Éve rendezvénysorozatot.

A Budapesti Állat- és Növénykert által rendezett Föld Fesztiválon 2015-ben első alkalommal a talaj is megjelent, Legyen talaj a lábunk alatt címmel, melyen az MTA Agrártudományi Kutatóközpont, Talajtani és Agrokémiai Intézet (MTA ATK TAKI) munkatársai nagysikerü interaktív talajtan bemutatót tartottak 2015. április 22 és 26 között. A Talajok Nemzetközi Éve e rendezvényein a gyerekek, a diákok és a rendezvény felnőtt érdeklődői négy témakörben (talajfizika, talajkémia, talajbiológia, illetve egyéb interaktív bemutatók), különböző ismereti szinteken találkozhattak a talajok jellemző tulajdonságaival és jelentőségével az emberek életében. A rendezvény egyik eredménye, hogy talajtanos szakembereket vontak be az állatkertben megvalósuló Energia Játszótér címü projekt megvalósításába, melynek során a talaj energiaraktározását (víz, hő, stb.) szeretnék bemutatni a gyerekeknek, speciálisan erre a célra tervezett játékokkal. A projekt 2016 végéig tart.

A Magyar Talajtani Társaság (MTT) Talajközpontú Termelés Konferenciája a szántóföldi hozamnövelés az alapoktól címü szakmai fórumot rendezett 2015. május 19-én Budapesten, a Nemzeti Élelmiszerlánc-biztonsági Hivatal, a Gabonatermelök Országos Szövetsége (GOSZ), az Agrova Kft., az Axiál Kft. és a Fertilia Kft. szakmai támogatásával. A rendezvényen Vancsura József, a GOSZ elnöke üdvözölte, hogy a termőföld a konferencia témája, aminek minősége és állapota nagymértékben meghatározza a teljes magyar agrárium jövöjét. Feldman Zsolt, a Földmüvelésügyi Minisztérium agrárgazdaságért felelős helyettes államtitkára a talajközpontú termelés kérdéseit tekintette át kormányzati szemszögből. Megfogalmazta, hogy a talaj állapotának romlása gazdasági szempontból sem szerencsés, mert romlik a talaj víztartó és tápanyag-szolgáltató képessége, melynek következtében a termelés jövedelmezősége is csökken. 
Michéli Erika, az MTT elnöke elmondta, hogy talajainkat megfelelően kell kezelnünk és megöriznünk. Ehhez azonban tudás alapú használat, a talajok ismerete és óvása szükséges. A körültekintő talajhasználat érdekében a tudomány, a politika, a gazdálkodók és a kiszolgáló ágazatok összefogása szükséges.

A Talajok Nemzetközi Évének ünneplésére az MTA ATK 2015. május 27-én Tudományos Konferenciát szervezett Martonvásáron. A konferencián talajtani kutatási eredményekről és további célokról, tervekről hangzottak el előadások. A plenáris előadók hazai szaktekintélyek voltak, így Blaskó Lajos, Lehoczky Éva, Michéli Erika, Németh Tamás, Tamás János és Várallyay György. A délutáni szekcióban Dombos Miklós, Farkas Csilla, Fodor Nándor, Makó András, Pásztor László, Rajkai Kálmán és Takács Tünde mutatta be a talajtan különböző tudományágainak legújabb eredményeit.

Keszthelyen az International Conference on Land Quality and Landscape Processes címü nemzetközi tudományos konferenciát 2015. június 2 és 4 között tartották. A konferenciához két tematikus mühelytalálkozó kapcsolódott Resource use efficiency in agriculture in Europe and China with special focus on land quality és Soil information in the Danube basin címmel. A rendezvény a Pannon Egyetem Georgikon Kara, az Európai Környezetvédelmi Ügynöksége, az Európai Bizottság Közös Kutatóközpontja és a Kínai Tudományos Akadémia Talajtani Intézete közös szervezésében zajlott. A konferencián megjelenteket Polgár Péter, a Pannon Egyetem Georgikon Karának dékánja köszöntötte. A plenáris előadásokat Körösi Csaba, a Köztársasági Elnöki Hivatalának Környezeti Fenntarthatóság Igazgatóság igazgatója, Gyuricza Csaba, a Mezőgazdasági és Vidékfejlesztési Hivatal igazgatója, Ronan Uhel, az Európai Környezetvédelmi Ügynökség Természetes Rendszerek és Fenntarthatóság programigazgatója, Alan Belward, az Európai Bizottság Közös Kutatóközpont Természeti Erőforrás Gazdálkodási Egység vezetője, Xiubin Li, a Kínai Tudományos Akadémia Földrajztudományi és Természetes Erőforrások Intézetének professzora, valamint Szőlősi-Nagy András, az UNESCO Víztudományi Oktató Intézet volt rektora tartotta.

A Nemzetközi talajleíró kurzus és verseny hazai válogató versenye Gödöllőn 2015. július 15-én zajlott, ahol a hét induló közül került ki a magyar csapat legjobb négy hallgatója, valamint egy „tréner” (coach). A válogató versenyen két talajszelvényt kellett részletesen jellemezni, osztályozni és értelmezni a FAO, illetve a nemzetközi elöírások szerint.

Nemzetközi részvétellel az egyik legjelentősebb hazai esemény a Nemzetközi talajleíró kurzust és verseny (International Field Course and Soil Judging Contest) volt 2015. szeptember 1 és 5 között. A rendezvényt a Magyar Talajtani Társaság, a Szent István Egyetem, a Nemzetközi Talajunió, az Európai Bizottság Közös Kutatóközpontja, az MTA Agrártudományi Kutatóközpont, illetve a Miskolci Egyetem szervezte. Az öt napos rendezvényre 28 országból (Afganisztán, Albánia, Anglia, Ausztrália, Bosznia-Hercegovina, Brazília, Dél-afrikai köztársaság, Dél-Korea, Fülöp-szigetek, Horvátország, Japán, Kenya, Koszovó, Laosz, Magyarország, Montenegró, Németország, Nigéria, Örményország, Ruanda, Spanyolország, Szerbia, Szudán, Tádzsikisztán, Törökország, Tunézia, Uganda, USA) érkező egyetemi- és PhD hallgatók 16 csapatban tanulhattak és mérhették össze tudásukat. A szakmai 
felkészülést a csapathoz tartozó trénerek segítették. Az első két nap előadások és terepi gyakorlatok voltak a Szent István Egyetem (SZIE) gödöllöi telepén. A következő két nap már teljes mértékben a terepi munkáról, és az ország különböző területein (Martonvásár, Atkár, Karcag) előforduló talajok megismeréséről szólt A martonvásári helyszínt az MTA ATK, a szakmai támogatást pedig az MTA ATK TAKI biztosította. A rendezvényt befejező nap Nádudvaron folyt a talajleíró és meghatározó verseny, csapatban és egyénileg. A feladat 2-2 talajszelvény leírása volt. A csapatversenyt az afrikai országokból érkezett résztvevőkből álló "Hakuna Matata" csapat nyerte. Az összesített csapatverseny (a csoportos és az egyéni eredmények együttes számításával) első díját a "Team USA" vehette át. A "H-moles" elnevezésü magyar csapat mindkét versenyszámban harmadik helyezést ért el. Laborczi Annamária egyéniben a 10. helyen végzett a 60 induló versenyzőből. A magyar csapatot Fodor Hella (SZIE), Laborczi Annamária (SZIE, MTA ATK TAKI), Hausz Imola (SZIE) és Mester Tamás (DE) alkotta, a versenyre felkészítő vezetőjük Kovács Károly (ME MFK) volt.

A Talaj és a Környezet - a klímaváltozás hatása a mezögazdaságra címü tudományos konferenciát 2015. szeptember 8-án a Debreceni Egyetem Mezőgazdasági-, Élelmiszertudományi és Környezetgazdálkodási Kara, a Kerpely Kálmán Doktori Iskola és Szakkollégium, valamint a KITE Mezőgazdasági Szolgáltató és Kereskedelmi Zrt. szervezte. A klímaváltozás hatásait és kihívásainak kezelési lehetőségeit vizsgáló interdiszciplináris kutatói team felkészítése a nemzetközi programokban való részvételre címmel tartott tudományos konferencián a klímaváltozás és a mezőgazdaság kapcsolatának legaktuálisabb kérdései szerepeltek. A találkozó több mint 400 résztvevője a hazai egyetemek, kutatóintézetek és vállalatok képviselöiből, valamint az államigazgatási szervek és a különböző szakmai kamarák képviselöiből állt. A konferencia résztvevőit Nagy János, a Debreceni Egyetem Mezőgazdaság-, Élelmiszertudományi és Környezetgazdálkodási Karának egyetemi tanára, Köpeczi-Bócz Tamás, az Emberi Erőforrás Minisztérium államtitkára, Györffy Balázs, a Nemzeti Agrárgazdasági Kamara elnöke, Gyuricza Csaba, a Mezőgazdasági és Vidékfejlesztési Hivatal elnöke, valamint Mezőszentgyögyi Dávid, a Herman Ottó Intézet föigazgatója köszöntötte. Németh Tamás, akadémikus a világ földhasználata fenntartható fejlődéséröl tartott előadást. Szabó Levente a KITE Zrt. vezérigazgatója a talajmüvelés hatását a talaj-növény rendszere elemezte. Búvár Géza címzetes egyetemi tanár pedig a tudományos kutatás és a gyakorlat kapcsolatáról beszélt.

A Kutatók éjszakája rendezvényen kiemelt módon a talaj szerepelt 2015. szeptember 25-én. A Földet értünk - Talajismeret mindenkinek címü interaktív talajtani bemutatót Martonvásáron, az MTA Agrártudományi Kutatóközpont épületében tartották. A nagy érdeklődést mutatja, hogy majd 1000 regisztrált fő volt kíváncsi az Agrártudományi Kutatóközpont munkájára, azon belül a talajok funkciói, tulajdonságai jelentőségére. Az interaktív program keretében az érdeklődők megismerkedhettek a talajok fizikai, kémiai és biológiai tulajdonságaival. Az érdeklődő gyerekek és felnőttek három talajféleséget gyúrhattak, talajszínt határozhattak meg Munsellskálával, sósavval cseppenthettek, talaj-szuszpenzió pH-ját állapíthatták meg, és talajlakó állatokat nézhettek meg mikroszkóp alatt. 
Nézz a talpad alá! - Mintavételtől a talajtérképekig címmel tartottak bemutató programot a Miskolci Egyetemi Kutatók Éjszakáján, immáron negyedszer. A fő téma a campus környezetének digitális talajtérképezési munkálatának elvégzése volt. A terepi felvételezés során 1 méteres bolygatatlan fúrt talajoszlopokból vettek mintákat, majd az ebből szerzett információkból elkészítendő térképek digitális munkáit kivetítőn magyarázták el a résztvevőknek.

Üde színfoltja volt a Talajok Nemzetközi Éve rendezvénysorozatnak a miskolci Herman Ottó Múzeum Pannon-tenger Földtörténeti és Természetrajzi Tárában felállított, $\boldsymbol{A z}$ éltető talaj címü időszaki kiállítás. A kiállítást a ME MFK FöldrajzGeoinformatika Intézet Természetföldrajz- Környezettan Tanszékének munkatársai 2015. október 28 és 2016. február 29. között rendezték meg. A megnyitón Szücs Péter, a Miskolci Egyetem Müszaki és Földtudományi Karának dékánja, illetve Kiss Gábor, Miskolc polgármestere köszöntötte az egybegyülteket. A kiállításon Magyarország talajait mutatták be eredeti szerkezetủ talaj-monolitokon. A kiállításhoz múzeumpedagógiai foglalkozások is kapcsolódtak óvodások és diákok számára. Az elöadásokon általános talajvédelmi feladatok, interaktív módszertani lehetőségek, valamint a talajok sokszínüsége szerepelt.

A Földművelésügyi Minisztérium és a Nemzeti Élelmiszerlánc-biztonsági Hivatal a Talajok Nemzetközi Éve rendezvénysorozat alkalmából Érték a talpad alatt címü időszaki interaktív kiállítást szervezett a Magyar Mezőgazdasági Múzeum és Könyvtárban 2015. november 25. és 2016. február 28. között. A kiállítást Zsigó Róbert élelmiszerlánc-felügyeletért felelős államtitkár nyitotta meg. Köszöntőjében hiánypótlónak és időszerünek nevezte a rendezvényt, mert az elmúlt ötven évben mindössze egy alkalommal volt hasonló tárlat. A kiállításon a talaj szerepe, fontossága, a talajt károsító, pusztító tényezők, a talajvédelem célja, a hazai talajtípusok, valamint a fenntartható talajhasználat kapott szerepet. Mindezt a bemutatott talajjal és talajvédelemmel kapcsolatos tárgyak, müszerek, könyvek, monolitok, diorámák szemléltették. A kiállítás megkülönböztetett figyelmet szentelt a gyerekek, a kisiskolások talajjal, termőfölddel kapcsolatos érdeklődésének felkeltésére, talajvédelmi ismereteinek bővítésére. Számukra interaktív játékokat is kihelyeztek.

Az MTA Kutatóintézetek Tárt kapukkal címü rendezvényen 2015. november 26-án az MTA ATK TAKI interaktív talajtani bemutatót szervezett. A bemutatón a gyerekek, a diákok és a rendezvény felnőtt érdeklődői találkozhattak a talajokkal. A korábbi interaktív programok hagyományaitól eltérően az Intézet egészét mutatták be az érdeklődőknek, vagyis az intézetben folyó tudományos kutató munkát az általános talajtan, a talajfizika, a talajkémia és a talajbiológia szakterületen. Ennek keretében az érdeklődők mind a négy tudományos osztályon, az Agrokémia és Növénytáplálási, a Talajbiológiai és -Biokémiai, a Környezetinformatikai és a Talajtani Osztály munkájába nyerhettek betekintést. Az Intézet laborjait is megtekinthették, ahol egyszerübb kísérleteket és méréseket láthattak.

A 2015 Talajok Nemzetközi Éve záró rendezvényét 2015. december 4-én tartották a Magyar Tudományos Akadémia Nagytermében. Az MTA Agrártudományok Osztálya, az MTA Környezettudományi Elnöki Bizottsága, a Magyar Talajtani Társaság és az Alapvető Jogok Biztosának Hivatala szervezésében összefoglalták az év főbb eseményeit, eredményeit. Az előadók vázolták a tudós társadalomra váró 
feladatokat a talajok megítélésének javítása érdekében. A rendezvény házigazdája Várallyay György akadémikus volt, aki köszöntőjében nyomatékosan hangsúlyozta a talajok földi életben játszott nélkülözhetetlen szerepét. Kiemelte továbbá a 2015. év jelentőségét, annak mind tudományos, mind nem tudományos hozadékát a hazai és nemzetközi talajtant művelők számára illetve a közéletben. Szabó Marcell, az AJBH a jövő nemzedék érdekvédelmét ellátó biztos-helyettes, Michéli Erika a Magyar Talajtani Társaság elnöke, valamint Németh Tamás akadémikus, az Agrártudományok Osztályának elnöke előadásukban hangsúlyozták a talaj megőrzésének és védelmének alapvető feladatának fontosságát, utalva arra, hogy a talaj is „az élet forrása".

Az MTA ATK TAKI munkatársai örömmel vállaltak szerepet a Látó-Mezö Közösségi Ökotábor és a Sasoló Természetbúvár táborok talajokra vonatkozó „tananyagának" összeállításában. Flórián Norbert, az MTA ATK TAKI fiatal munkatársa szerepet vállalt az ökotáborban. Hozzájárult a 2015-ben „vállalt” TAKI „misszióhoz”, vagyis ahhoz, hogy a Talajok Nemzetközi Évében minél több gyermek ismerkedjen meg a talajélet formáival. A Sasoló Természetbúvár táborok vezetője Kocsis Zsuzsa környezetpedagógus és táborvezető teljes odaadással mutatta be a talajok fizikai, kémiai és biológiai tulajdonságait az 5-13 éves korosztályú gyermekeknek. E táborokban 2015-ben közel 2000 gyerek ismerkedett meg interaktív programokon a talajok alapvető tulajdonságaival.

A Miskolci Egyetem Müszaki és Földtudományi Kar Földrajz-Geoinformatika Intézete Természetföldrajz - Környezettan Tanszékének munkatársai számos rendezvényt szerveztek a talajtan terepi munkái, a talajok sajátos tulajdonságai, illetve a talajok térképezése megismertetésére. Ilyen esemény volt a 2015. március 22-i Viz Világnapja a Talaj Évében a Pannon-tenger Múzeumában, valamint a 2015. április 10 és 11 között a VIII. Országos Középiskolai Földtudományi Diákkonferencián tartott „A talajon nem csak állsz, hanem élsz is” című látványóra, továbbá a 2015. április 26-án, Lillafüreden rendezett Herman Ottó napja rendezvény, a 2014. május 28-i 16. Nemzetközi Junior Öko-Expert Projekthét és a 2014. december 4 és 5 közötti Miskolci Egyetem Nyílt Napok, „A talajon nem csak állsz, hanem élsz is" elnevezésü látványóra.

A 2009-es budapesti Agrogeológia Konferenciára összeállított Történelmi arcképcsarnok professzorainak sorát a Talajok Nemzetközi Éve alkalmából kibővítve készült el az MTA Talajtani, Vizgazdálkodási és Növénytermesztési Bizottsága (TVNT) Professzori Arcképcsarnoka, melyben a talajtan, a mezőgazdasági vízgazdálkodás és a növénytermesztéstan tudományterületén maradandót alkotott tudósokat gyüjtötték össze és mutatták be. A portrékból, rövid életrajzokból és személyes információkból összeállított dokumentum a talajtani tudomány kiemelkedő kutatóinak kívánt emléket állítani és munkájukat megismertetni a jelen és a jövő generációval.

Érkezett: 2016. május 12.

Koós Sándor

Postai cím: KOÓS Sándor, MTA ATK Talajtani és Agrokémiai Intézet, 1022 Budapest, Herman Ottó út. 15. E-mail: koos@rissac.hu 